\title{
Rapid detection of Helicobacter pylori by the naked eye using DNA aptamers
}

Hangjie $\mathrm{Wu}^{\mathrm{a}, \mathrm{b}}$, Lide $\mathrm{Gu}^{\mathrm{a}}$, b, Xiaoyi Ma ${ }^{\mathrm{a}, \mathrm{b}}$,Xueqing Tian ${ }^{\mathrm{a}, \mathrm{b}}$,Shihui Fan ${ }^{\mathrm{a}, \mathrm{b}}$, Mingcan

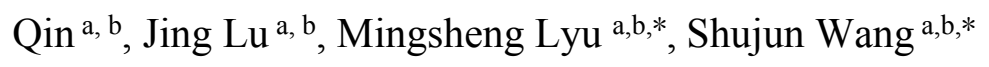

ajiangsu Key Laboratory of Marine Bioresources and Environment/Jiangsu Key Laboratory of Marine Biotechnology, Jiangsu Ocean University, Lianyungang, 222005, PR China

${ }^{\mathrm{b} C o-I n n o v a t i o n ~ C e n t e r ~ o f ~ J i a n g s u ~ M a r i n e ~ B i o-i n d u s t r y ~ T e c h n o l o g y, ~ J i a n g s u ~ O c e a n ~ U n i v e r s i t y, ~}$ Lianyungang, 222005, PR China
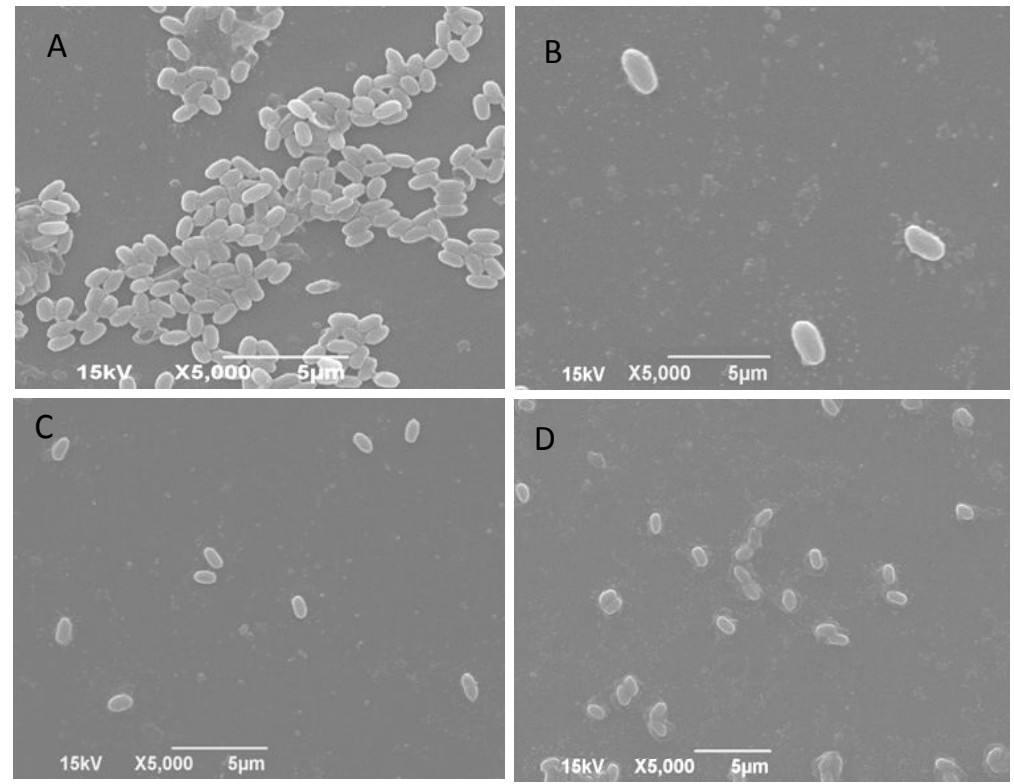

Figure S1. SEM image for H. pylori. (A) the first culture, (B) the second culture, (C) the third culture, (D) fourth culture.
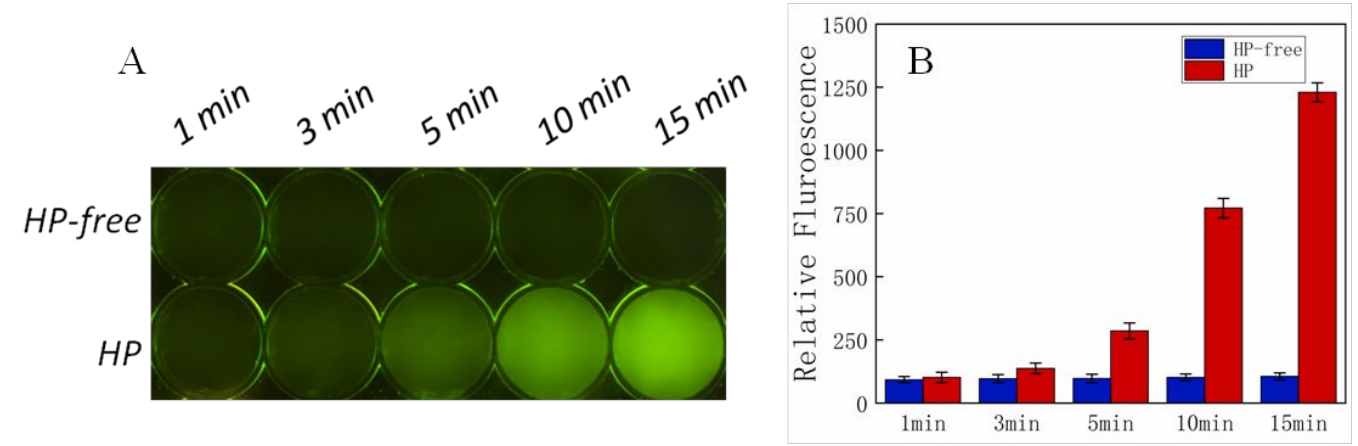

Figure S2. Apple juice sample (A) sensor reaction with time, (B) the fluorescence measurement. (HP-free: H. pylori-free, HP: H. pylori-added) 